\title{
Synthesis of Diazacrown Ethers Containing Phenolic Side Arms and Their Complex with Divalent Metal Ions
}

\author{
Ki-Whan Chi, "Yoon Soo Ahn, Kwang Taeg Shim, Hwang Huh, and Jeong Soo Ahn \\ Department of Chemistry: University of Ulsan. Utsan 680-749, Korea \\ Recened February 4,2002
}

\begin{abstract}
The aminomethylation of phenols with para-substituents by the Mannich reaction has successfully been accomplished to produce the Mannich bases 2-6. The compounds 7-8 have also been synthesized in order to identify the effect of the side arms and the macrocycle in the complex formation. Protonation constants and stability constants of the double armed diaza-18-crown-6 ethers 2-7 with metal ions have been determined by potentiometric method at $25^{\circ} \mathrm{C}$ in $95 \%$ methanol solution. Under a basic condition $(\mathrm{pI} 1>8.0$ ), the doublearmed crown ethers 2-6 revealed stronger interaction with divalent metal ions than the simple diazacrown ether 1. The stability constants with these metal ions were $\mathrm{Co}^{21}<\mathrm{Ni}^{21}<\mathrm{Cu}^{21}>\mathrm{Zn}^{2}$ in increasing order, which are in accordance with the order of the Williams-lrving series. The stability constants with alkali earth metal ions were $\mathrm{Ca}^{2-}<\mathrm{Sr}^{2}<\mathrm{Ba}^{21}$ in increasing order, which may be explained by the concept of size effect. It is noteworthy that the hosts $2-6$. which have phenolic side arms and a macrocycle, bind stronger with metal ions than the hosts 1 and 7 . On the other hand, the host $\mathbf{8}$, which has phenolic side arms with a pyperazine ring, provided comparable stability constants to those with the host 3 . These facts demonstrate that phenolic side arms play a more important role than the azacrown ether ring in the process of making a complex with metal ions especially in a basic condition. In particular, the $\log \mathrm{K}_{\mathrm{v}}$. values for complexation of divalent metal ions with the hosts $2-6$ had the sequence, i.e., $2\left(\mathrm{R}^{-} \mathrm{OCII}_{3}\right)<\mathbf{3}\left(\mathrm{R}^{-} \mathrm{Cl} \mathrm{I}_{3}\right)<\mathbf{4}(\mathrm{R}-\mathrm{I} 1)<5(\mathrm{R}-\mathrm{Cl})<6\left(\mathrm{R}^{-} \mathrm{CF}\right.$. $)$. The stability constants of the hosts 5 and 6 containing an electron-withdrawing group are larger than those of the hosts $\mathbf{2}$ and $\mathbf{3}$ containing an electron-donating group. This substituent effect is attributed to the solvent effect in which the aryl oxide with an electron-donating group has a tendency to be tied strongly with protic solvents.
\end{abstract}

Keywords : Diazacrown ethers, Phenolic side arms, Complex with divalent metal ions.

\section{Introduction}

Double armed crown ethers and related macrocycles represent a new class of synthetic cation-binders which are characterized by a parent macrocyclic ligand and a cationligating functionalized arm. ${ }^{1}$ With this class of compounds, the guest cation can be wrapped in such a way that additional donor groups on the flexible arms would provide further coordination to the guest cation trapped in the parent macro-ring. The structure of metallic complexes with double armed crown ethers is similar to that of bicyclic cryptand compounds, but a higher mobility of the ligating two arms attached to the crown ether ring may permit stable and dynamic complexation. ${ }^{2}$ Since their cation-binding behaviors are strongly dependent on the coordination characters of their side arms, an introduction of a potential binding site on the side arms is a promising strategy for the functionalization of crown ether compounds. In this sense, diazacrown ether with phenolic side-arms might be an interesting host molecule to be studied since oxygen atoms in the phenolic side-arms could function as extra ligands in the formation of a complex with a metal cation guest.

One plausible way for the synthesis of that kind of host is the Mannich reaction" between azacrown ethers, formaldehyde and phenolic derivatives. Although substituted phenols are commonly used in the Mannich reaction, it has been difficult to undergo aminomethylation of various phenols with sterically hindered amines. Instead of direct aminomethylation, bulky azacrown ethers were treated with the methanol solution of paraformaldehyde to provide the $N$ methoxymethyl-substituted azacrown ethers, which subsequently gave the Mannich bases by a reaction with a proper substrate. ${ }^{4}$ However, a more convenient one-pot method $^{5_{i 1}}$ has been recently developed by $\mathrm{Chi}$ and coworkers using 1,4,10,13-tetraoxa-7,16-diazacyclooctadecane, paraformaldehyde and phenolic derivatives in benzene to produce double-armed diazacrown ethers in good yields.

In this paper we report the synthesis of a variety of the double-armed crown ethers 2-7 and the mimic host $\mathbf{8}$, and the binding properties between the receptors and various divalent metal ions. A complex formation study has been studied by potentiometry and 'H-NMR under a basic condition. Consequently, a substituent effect of the phenol ring of 2-6 has been established and the function of the phenolic

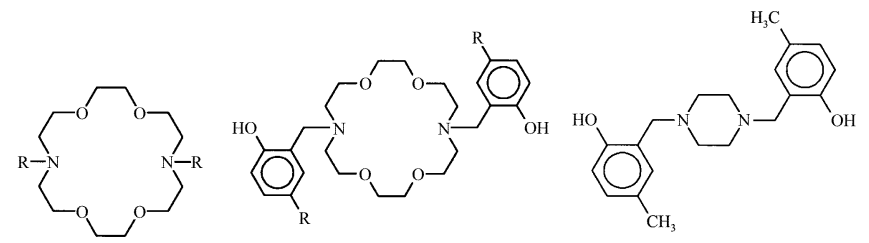

$\begin{array}{lll}\mathbf{1}: \mathrm{R}=\mathrm{H} & \mathbf{2}: \mathrm{R}=\mathrm{OCH}_{3} & \mathbf{3}: \mathrm{R}=\mathrm{CH}_{3} \\ \mathbf{7}: \mathrm{R}=\text { benzyl } & \mathbf{4}: \mathrm{R}=\mathrm{H} & \mathbf{5}: \mathrm{R}=\mathrm{CI} \\ & \mathbf{6}: \mathrm{R}=\mathrm{CF}_{3} & \end{array}$ 
side arms in the complex formation has been elucidated.

\section{Experimental Section}

Synthesis. Starting materials were purchased from Aldrich chemical company and used without further purification. All chromatography solvents were of analytical grade and freshly distilled prior to use. Thin-layer chromatographic analyses were conducted by using a pre-coated TI.C plate $\left(60 \mathrm{~F}_{254}, 20 \mathrm{~cm} \times 20 \mathrm{~cm}\right)$ purchased from Merck company. Silica gel (230-400 mesh) was used in flash chromatography and deactivated by $\mathrm{ca} .2 \%$ triethylamine in eluent solution.

IR spectra were recorded on a Mattson 5000 (UNICAM) spectrometer $(\mathrm{KBr})$. Melting points of the prepared compounds were determined on an Aldrich melt temp apparatus and were uncorrected. ${ }^{1} \mathrm{H}$ and ${ }^{13} \mathrm{C}$ NMR $(300 \mathrm{MHz}, 75.48$ $\mathrm{MHz}$, respectively) spectra were recorded using a Varian Unity-plus 300 FT NMR or Bruker AM-300 NMR spectrometer. Mass spectra were obtained using a KRATOS Profile HV-3 or Shimadzu GC MS-Q.P $5050(70 \mathrm{eV})$ spectrometer with a direct insertion probe. All the host molecules were synthesized by the known procedure.

Preparation of 7,16-Bis|(5'-trifluoromethyl-2'-hydroxyphenyl) methyl]-1,4,10,13-tetraoxa-7,16-diazacycloocta-

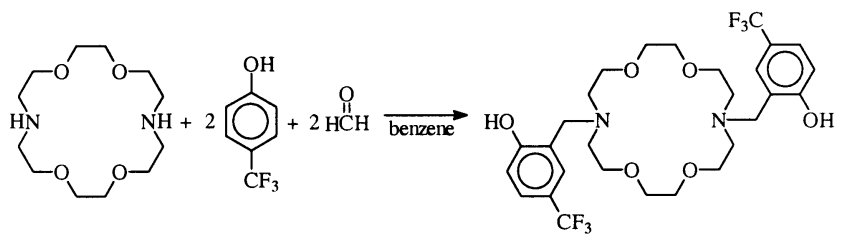

decane (6). To a solution of 4-(trifluoromethyl)phenol (148 $\mathrm{mg}, 0.91 \mathrm{mmol}$ ) and paraformaldehyde (27 $\mathrm{mg}, 0.91 \mathrm{mmol}$ ) in dry benzene $(8 \mathrm{ml}$.) was added 1,4,10,13-tetraoxa-7,16diazacyclooctadecane $(100 \mathrm{mg}, 0.38 \mathrm{mmol})$ at room temperature. Then, the resulting mixture was heated at reflux for 18-22 hrs. After removing the benzene at reduced pressure from the reaction mixture, the final product 6 was isolated by column chromatography on silica gel using hexane-ethyl acetate.

white solid; mp 104- $105^{\circ} \mathrm{C}$; yield $45 \%$; ' $\mathrm{H}-\mathrm{NMR}\left(\mathrm{CDCl}_{3}\right.$, $300 \mathrm{MHz}) 2.86 \delta(\mathrm{t}, J=4.1 \mathrm{~Hz}, 8 \mathrm{H}), 3.6 \mathrm{l}(\mathrm{s}, 8 \mathrm{H}), 3.67(\mathrm{t}, J=$ $5.3 \mathrm{~Hz}, 8 \mathrm{H}), 3.85(\mathrm{~s}, 4 \mathrm{H}), 6.85(\mathrm{~d}, J=8.4 \mathrm{~Hz}, 2 \mathrm{H}) .7 .23(\mathrm{~m}$, $2 \mathrm{H}), 7.40(\mathrm{~d}, 2 \mathrm{H}, J=8.4 \mathrm{~Hz}) ;{ }^{13} \mathrm{C}-\mathrm{NMR}(\mathrm{CDCl}, 75.48$ MHz) $\delta 53.68,58.20,68.80,70.77,116.45,120.97,122.54$, 123.49, 125.69, 126.03, 161.09: IR $\left(\mathrm{cm}^{-1}\right) 3435,2887,1616$, 1334. 1112; MS $m / \varepsilon$ (rel. intensity) $610\left(\mathrm{M}^{+}, 7\right), 591$ (5), 473 (3), $435(8), 361$ (14), $306(51), 261$ (30), 175 (100), 127 (35). $56(62)$.

Preparation of 1,4-Bis|(5'-methyl-2'-hydroxyphenyl)-

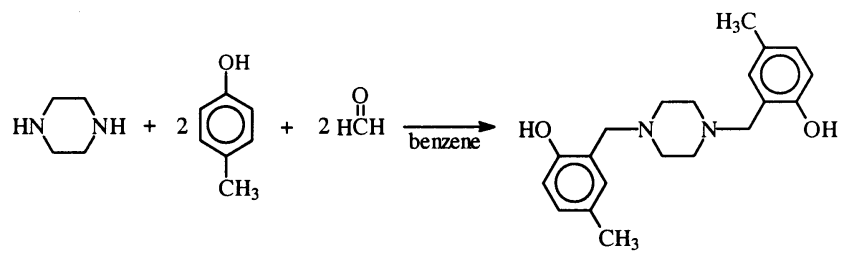

methyl|piperazine (8). To a solution of p-cresol (108 mg. $0.91 \mathrm{mmol}$ ) and paraformaldehyde $(27 \mathrm{mg} .0 .91 \mathrm{mmol})$ in dry benzene $(8 \mathrm{ml})$ was added piperazine $(100 \mathrm{mg}, 0.38$ mmol) at room temperature. Then, the resulting mixture was heated at reflux for 18-22 hrs. After removing the benzene at reduced pressure from the reaction mixture, the final product 8 was purified by recrystalization using methanol.

white solid; mp 225-226 ${ }^{\circ} \mathrm{C}$; yield $41 \%$; ' ${ }^{\mathrm{H}}$-NMR (CDCl: $300 \mathrm{MH} z) \delta 2.23(\mathrm{~s}, 6 \mathrm{H}), 2.48-3.1$ (m, piperazine, $8 \mathrm{H}$ ), 3.66 $(\mathrm{s}, 4 \mathrm{H}), 6.74(\mathrm{~s}, 1 \mathrm{H}), 6.81(\mathrm{~m}, 2 \mathrm{H}), 7.02(\mathrm{~d}, J=1.8 \mathrm{~Hz}, 2 \mathrm{H})$; ${ }^{13} \mathrm{C}-\mathrm{NMR}\left(\mathrm{CDCl}_{3}, 75.48 \mathrm{MH} 7.\right) \delta 20.42,52.35,61.22$. $115.79,120.50,128.35,129.28,129.33,155.07: \mathrm{IR}\left(\mathrm{cm}^{-1}\right)$ $3638,2973,1589,1011$; MS $m / s$ (rel, intensity) $326\left(\mathrm{M}^{-}\right.$. $58), 311(20), 205(70), 150(51), 136(17), 121(100), 85$ $(80), 56(48)$.

Potentiometric measurements. Potentiometric titrations were carried out with Metrohm $736 \mathrm{GP}$ titration system fitted with a glass electrode and $\mathrm{Ag} / \mathrm{AgCl}$ reference electrode system. The $\mathrm{pH}$ electrode was checked with standard $\mathrm{pH} 4.00, \mathrm{pH} 7.00$ and $\mathrm{pH} 10.0$ buffers before each titration. $\mathrm{Ca}\left(\mathrm{NO}_{3}\right)_{2}, \mathrm{SrCl}_{2}, \mathrm{BaCl}_{2}, \mathrm{CoCl}_{2}, \mathrm{NiCl}_{2}, \mathrm{CuCl}_{2}, 7 \mathrm{nCl}_{2}$ and $\mathrm{Pb}\left(\mathrm{NO}_{5}\right)_{2}$ were purchased as $99.9+\%$ purity and used without further purification. The stock solution was prepared from HPLC grade methanol and triply-distilled water. A typical solution for potentionetric equilibrium studies consisted of the following reagents: $1.0 \times 10^{-4} \mathrm{M}$ ligand, $1.0 \times$ $10^{-4} \mathrm{M}$ metal ion, $2.4 \times 10^{-4} \mathrm{M} \mathrm{HCl}$ and $1.0 \times 10^{-2} \mathrm{M}$ $\left(\mathrm{CH}_{3}\right)_{1} \mathrm{NCl}$ of background electrolyte in $95 \%$ methanol solution. Fvery titration was performed under a $\mathrm{CO}_{2}$-free nitrogen atmosphere and the cell was thermostated to $25.0 \pm 0.1^{\circ} \mathrm{C}$.

(a) Protonation constants measurements: The $\mathrm{pH}$ profile of an acidified host was obtained in the absence of metal ion. An acidified host solution (24 mL) was prepared and stirred for 15 min for equilibrium, it was then titrated by slow addition $\left(0.015 \mathrm{~mL}\right.$, at a time) of $1.0 \times 10^{-2} \mathrm{M}$ $\left(\mathrm{CH}_{3}\right)_{4} \mathrm{NOH}$ solution. Multiple sets of data files containing $70-90$ points were used in calculating the protonation constants. The protonation constants were calculated using the progran PKAS. ${ }^{6}$

(b) Stability constants measurements: The $\mathrm{pH}$ profile of an acidified host-metal ion (1:1 molar ratio) solution was determined according to the procedure (a). Stability constants of complexes were calculated by the iterative Fortran program BES $]^{6}$ The average deviation between observed and calculated $\mathrm{pH}$ was less than $0.015 \mathrm{pH}$ units.

'H NMR measurements. 'H NMR spectra of the free hosts 1-8 and their complexes were recorded using a Varian Unity-plus 300 spectrometer at $25.0 \pm 0.1{ }^{\circ} \mathrm{C}$ in the $\mathrm{CD}_{3} \mathrm{OD}$ / $\mathrm{CDCl}_{3}(4: 1 \mathrm{v} / \mathrm{v})$. Tetramethylsilane was used as an internal standard material. For elucidation of the complex composition, NMR titration experiments were conducted with various molar ratios of metal to host (from $0: 1$ up to $9: 1$ ). ${ }^{7}$ Excess bases (2.2 equivalents of $\mathrm{Me}_{4} \mathrm{NOH}$ versus 1.0 equivalent of host) were added just before each run and chemical induced shifts (CIS) were evaluated. 


\section{Results and Discussion}

The Mannich reaction for the synthesis of the ortho aminomethylated phenols 2-6 was accomplished according to the known procedure. ${ }^{5}$ The compound 7 with benzyl sidearms was also easily prepared by a treatment of 1 with benzyl bromide or it is commercially available at a resonable price. Aminomethylation of $p$-cresol with piperazine and paraformaldehyde in benzene gave the Mannich base 8 without any difficulty.

The NMR titration experiments with $\mathrm{Sr}^{7-}$ and $7 \mathrm{n}^{2-}$ ions indicated that CIS were maximized when the metal to host mole ratio reached 1.0. This fact showed that each of these ions formed a $1: 1$ complex with a host.

The equilibrium constant measurements were carried out using the potentiometric titration technique in $95 \% \mathrm{MeOH}$ at $25.0^{\circ} \mathrm{C}$. For the protonation constants determination, a standard $\mathrm{HCl}$ solution was added to protonate all basic sites of the host and the solution was then titrated with a standardized $\mathrm{Me}_{4} \mathrm{NOH}$ solution. For the stability constants. metal salt was added to the protonated host solution, and in the titration process all the acidic protons were released from the host. The protonation equilibrium constants and stability constants obtained were defined as follows:

$$
\begin{aligned}
& \mathrm{l}^{2-}+\mathrm{H}^{+} \rightleftharpoons \mathrm{I},-\mathrm{H} \quad \mathrm{K}_{\mathrm{I}}{ }^{\mathrm{H}}=\left[\mathrm{I}^{-} \mathrm{H}\right] /\left[\mathrm{l}^{2-}\right]\left[\mathrm{H}^{-}\right] \\
& \mathrm{L}^{-} \mathrm{H}-\mathrm{H}^{+} \rightleftharpoons \mathrm{LH}_{2} \quad \mathrm{~K}_{2}{ }^{\mathrm{H}}=\left[\mathrm{LH}_{2}\right] /\left[\mathrm{L}^{-} \mathrm{H}\right]\left[\mathrm{H}^{-}\right] \\
& \mathrm{LH}_{2}+\mathrm{H}^{-} \rightleftharpoons \mathrm{LH}_{3} \quad \mathrm{~K}_{3}{ }^{\prime \prime}-\left[\mathrm{LH}_{3}^{\prime}\right]\left[\mathrm{LH}_{2}\right]\left[\mathrm{H}^{\prime}\right] \\
& \left.\left.\mathrm{LH}_{3}{ }^{\prime}+\mathrm{I}^{\prime} \rightleftharpoons \mathrm{LH}_{4}{ }^{2 \prime} \quad \mathrm{K}_{4}{ }^{\prime \prime}-\left[\mathrm{LI}_{4}{ }^{2 \cdot}\right] / \mid \mathrm{LH}_{3}{ }^{\prime} \|\right]\right]^{\prime} \mid \\
& \text { 1. } \mathrm{H}_{2}+\mathrm{M}^{2+} \rightleftharpoons \mathrm{Ml}_{2} \mathrm{H}_{2}{ }^{2-} \mathrm{K}_{\mathrm{MLI}[2}=\left[\mathrm{MI}, \mathrm{H}_{2}{ }^{2+}\right] /\left[\mathrm{L}_{2} \mathrm{H}_{2}\right]\left[\mathrm{M}^{2-}\right] \\
& \mathrm{L}^{-} \mathrm{H}-\mathrm{M}^{2-} \rightleftharpoons \mathrm{MLH}^{+} \mathrm{K}_{\mathrm{Ml} .1 ! \mathrm{l}}=[\mathrm{MLH}] /\left[\mathrm{L}^{-} \mathrm{ll}\right]\left[\mathrm{M}^{2 \prime}\right] \\
& \mathrm{L}^{2-}+\mathrm{M}^{21} \rightleftharpoons \mathrm{ML} \quad \mathrm{K}_{\mathrm{Ml} .}=|\mathrm{ML}| /\left[\mathrm{L}^{2-}\right]\left|\mathrm{M}^{2 \cdot}\right|
\end{aligned}
$$

Protonation-deprotonation processes of the tested compounds were expressed by equations (1), (2), (3) and (4). Equations (5) and (6), (7) describe a complex formation in a neutral or alkaline medium, respectively. Where [ $\left.\mathrm{L}_{2} \mathrm{H}_{2}\right]$ and $\left[\mathrm{M}^{2+}\right]$ represent the equilibrium concentrations of free host and metal cation, respectively. The $\log \mathrm{K}_{\mathrm{n}}{ }^{\mathrm{H}}$ values for the protonation of the hosts are listed in Table 1.

The compounds 2-6 and 8 had four protonation constants

Table I. Logarithms of the protonation constants for the hosts 1-8 in $95 \%$ methanol solution at $25^{\circ} \mathrm{C}$ and $\mu \quad 0.01 \mathrm{M}\left(\mathrm{CH}_{3}\right)_{4} \mathrm{NCl}$

\begin{tabular}{cccc}
\hline Host & $\log \mathrm{K}_{1}{ }^{\mathrm{ll}}$ & $\log \mathrm{K}_{2}{ }^{13}$ & $\log \mathrm{K}_{i}{ }^{11}$ \\
\hline $\mathbf{I}$ & 8.65 & 7.11 & - \\
& $(8.94)^{\mathrm{x}}$ & $(7.81)^{8}$ & \\
$\mathbf{2}\left(\mathrm{R}=\mathrm{OCH}_{5}\right)$ & 11.49 & 8.94 & 5.74 \\
$\mathbf{3}\left(\mathrm{R}=\mathrm{CH}_{3}\right)$ & 11.28 & 8.71 & 6.65 \\
$\mathbf{4}(\mathrm{R}=\mathrm{H})$ & 11.24 & 9.77 & 5.74 \\
$\mathbf{5}(\mathrm{R}=\mathrm{Cl})$ & 10.95 & 10.09 & 6.16 \\
$\mathbf{6}(\mathrm{R}=\mathrm{CF})$ & 10.52 & 9.69 & 7.11 \\
$\mathbf{7}$ & 8.81 & 7.77 & - \\
$\mathbf{8}$ & 11.06 & 9.02 & 5.08 \\
\hline
\end{tabular}

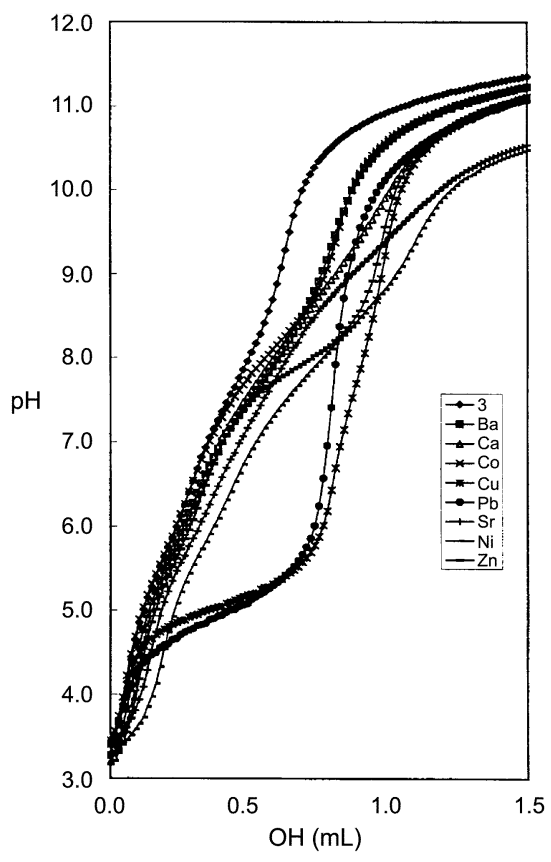

Figure 1. Potentiometric equilibrium curves for the complexes belween the hos 3 and $\mathrm{Ca}^{2-} \cdot \mathrm{Sr}^{2+} \cdot \mathrm{Ba}^{2-} \cdot \mathrm{Co}^{2+} \cdot \mathrm{Ni}^{2+} \cdot \mathrm{Cu}^{2+}, \% \mathrm{n}^{2-}$ or $\mathrm{Pb}^{21}$ as a function of added (CH, $\mathrm{H}_{3} \mathrm{NO} \mathrm{Cl}$ in $95 \%$ methanol solution at $25^{\circ} \mathrm{C}$.

in which the $\log \mathrm{K}_{1}{ }^{\mathrm{H}}$ and $\log \mathrm{K}_{2}{ }^{\mathrm{H}}$ values correspond to the protonation of the phenoxide groups. Also, the $\log \mathrm{K}_{3}{ }^{\mathrm{H}}$ and log $\mathrm{K}_{t}{ }^{\mathrm{H}}$ values are related with the protonation of the macroring $\mathrm{N}$-pivots, and the $\log \mathrm{K}_{4}{ }^{\mathrm{H}}$ values are very sinall and negligible. On the other hand, the compounds $I$ and 7 have two protonation constants, respectively, the $\log \mathrm{K}_{\mathrm{I}}{ }^{\mathrm{H}}$ and $\log \mathrm{K}_{2}{ }^{\mathrm{H}}$ values were attributed to the protonation of the azacrown $\mathrm{N}$-pivots. Potentiometric titration curves of the host 3 with various metal cations are shown in Figure 1.

It should be noted that the titration curve with $\mathrm{Pb}^{2+}$ or $\mathrm{Cu}^{2-}$ in Figure 1 was distinguished from those with other ions since the $\mathrm{pH}$ of the solution with lead or copper ion remained less than 6.0 even after $0.75 \mathrm{~mL}$ of $\mathrm{Me}_{4} \mathrm{NOH}$ solution was added. This fact gives us a good qualitative clue that lead and copper ions would make a stronger interaction with the host 3 than other ions. I he stability constants $\left(\log \mathrm{K}_{\mathrm{NL}}\right)^{\circ}$ of $\mathbf{1 - 8}$ with metal cations are listed in Jable 2 .

As shown in Jable 2, the stability constants for alkali earth metal ions were $\mathrm{Ca}^{2+}<\mathrm{Sr}^{2+}<\mathrm{Ba}^{2-}$ in increasing order, which may be explained by the size effect between a metal ion and diazacrown ring. The stability constants with transition metals were $\mathrm{Co}^{2+}<\mathrm{Ni}^{2-}<\mathrm{Cu}^{2-}>\mathrm{Zn}^{2-}$ in increasing order. which are in accordance with the order of the WilliamsJrving series. "In particular, binding with $\mathrm{Cu}^{2+}$ and $\mathrm{Pb}^{2+}$ ions was stronger than other metal ions. The large stability constants of $\mathrm{Cu}^{2+}\left(\mathrm{d}^{9}\right)$ might be attributed to a Jahn-']eller distortion. ${ }^{12}$ Also, $\mathrm{Pb}^{2+}$ ion seemed to make a soft-soft interaction with 2-6 to have big stability constants. It is noteworthy that the hosts 2-6 containing phenolic side arms and a macrocycle bind more strongly with metal ions than 
Table 2. Logarithm of the stability constants for the hosts 1-8 with various metal jons in $95 \%$ methanol solution at $25^{\circ} \mathrm{C}$ and $\mu=0.0 \mathrm{l} \mathrm{M}$ $\left(\mathrm{CH}_{3}\right)_{4} \mathrm{NCl}$

\begin{tabular}{|c|c|c|c|c|c|c|c|c|}
\hline Ilost & $\mathrm{Ca}^{2}$ & $\mathrm{Sr}^{2}$ & $13 a^{2}$ & $\mathrm{Co}^{2}$ & $\mathrm{Ni}^{2}$ & $\mathrm{Cu}^{2}$ & $7 n^{2}$ & $\mathrm{~Pb}^{-\cdot}$ \\
\hline \multirow[t]{2}{*}{1} & 3.75 & 6.01 & 6.56 & 3.82 & 4.04 & 8.03 & nd & 8.85 \\
\hline & $(3.81)^{10}$ & $(5.89)^{10 \dot{ }}$ & $(5.90)^{10}$ & - & $(4.13)^{10}$ & $(8.48)^{10}$ & $(4.84)^{10}$ & $(9.48)^{1 \mathrm{ij}}$ \\
\hline $2(\mathrm{R}=\mathrm{OCH})$ & 8.15 & 7.54 & 11.53 & 7.20 & 7.85 & 13.35 & 8.14 & 8.79 \\
\hline $3\left(\mathrm{R}=\mathrm{C}_{3}\right)$ & 7.85 & 7.93 & 11.82 & 7.98 & 8.07 & 13.53 & 8.44 & 10.34 \\
\hline $4(\mathrm{R}=\mathrm{H})$ & 8.29 & 7.94 & 11.76 & 8.53 & 8.73 & 13.75 & 8.62 & 12.12 \\
\hline$S(R=C . I)$ & 8.43 & 9.39 & 12.51 & 8.54 & 9.31 & 14.85 & 8.93 & 13.11 \\
\hline $6\left(\mathrm{R}=\mathrm{C} \mathrm{F}_{3}\right)$ & 8.93 & 9.41 & 14.06 & 8.71 & 9.01 & 16.70 & 9.27 & 15.21 \\
\hline 7 & 2.0 & 5.17 & 5.81 & 2.24 & 2.41 & 6.50 & 2.42 & 8.09 \\
\hline 8 & nd & 8.42 & 9.78 & nd & nd & 12.29 & nd & 10.88 \\
\hline
\end{tabular}

nd: nol determined

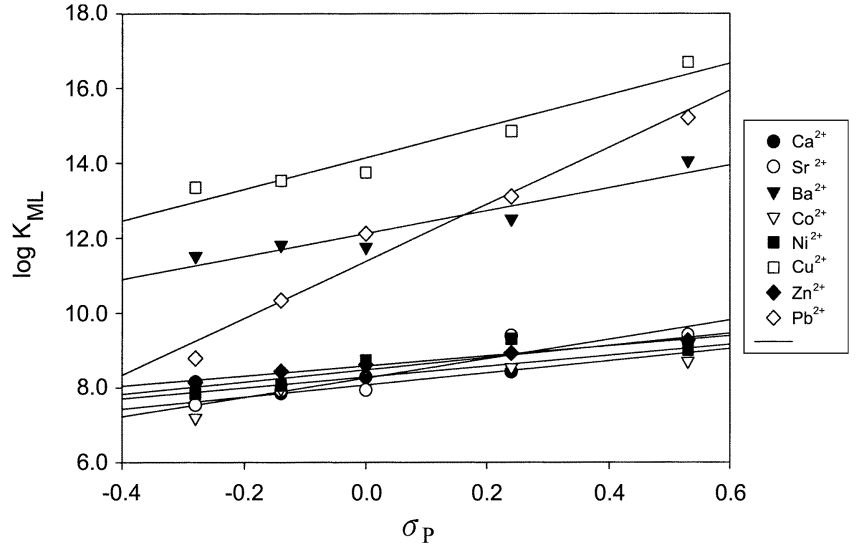

Figure 2. Hammett plots for the complex hetween 2-6 and various divalent metal ions in $95 \%$ methanol solution at $25^{\circ} \mathrm{C}$ and $\mu \quad 0.01$ $\mathrm{M}\left(\mathrm{ClI}_{3}\right)_{6} \mathrm{NC \textrm {Cl }}$.

the hosts 1 and 7 . This fact tells us that hydroxy group on the side arms played an important role in the complex formation. The shapes and the binding sites of the hosts 2-6 should be the same as each other except in the para substituent of the phenol groups. Such substituents exert influence on the phenolic acidity, and in turn result in different stabilities of the complexes. In particular, the log $K_{N \mid L}$ values for complexation of divalent metal ions with the hosts 2-6 have the sequence, i.e., $2\left(\mathrm{R}=\mathrm{OCH}_{3}\right)<3\left(\mathrm{R}=\mathrm{CH}_{3}\right)$ $<4(\mathrm{R}=\mathrm{H})<5(\mathrm{R}=\mathrm{Cl})<6\left(\mathrm{R}=\mathrm{Cr}_{3}\right)$. The stability constants of hosts containing an electron-withdrawing group are larger than those of hosts containing an electron-donating group. This substituent effect is attributed to the solvent effect in which the aryl oxide with an electron-donating group has a tendency to be tied strongly with protic solvents.

A plot of $\log \mathrm{K}_{1}{ }^{\mathrm{H}}$ against the substituent constants $\left(\sigma_{\mathrm{p}}\right)$ shows a straight line, indicating that the Hammett correlation $^{\text {1. }}$ holds for the para substituents of the side arms. Also, plots of log $\mathrm{K}_{\mathrm{ML}}$ values versus $\sigma_{\mathrm{p}}$ provide a good linear correlation in every case. (Figure 2)

As indicated in Figure 2, the reaction constants $(\rho)$ with $\mathrm{Pb}^{2-}, \mathrm{Cu}^{2-}$ and $\mathrm{Ba}^{2-}(7.59,4.20$ and 3.04 respectively) are much bigger than those (1.35-2.58) with other metal ions, which demonstrates that the three ions are more sensitively affected by the substituent in the phenolic ligand during the complex formation. In addition, the host 8 which has a piperazine moiety instead of a diazacrown ring was examined as a host. The stability constants of 8 with $\mathrm{Sr}^{2-}$, $\mathrm{Ba}^{2+}, \mathrm{Cu}^{2+}$ and $\mathrm{Pb}^{2+}$ were determined, and the result showed that the stability constants of 8 were comparable with those of 3 in spite of the absence of a crown ring in 8 . This strongly indicates the fact that the phenolic groups in $\mathbf{8}$ exert a crucial influence on the complex formation with metal ions especially under a basic condition.

In conclusion, the aminomethylation of phenols with parasubstituents by the Mannich reaction has been successfully accomplished to produce the double-armed crown ethers 26. The compounds $\mathbf{1}$ and 8 have also been synthesized in order to compare the effects of side arms and/or the macrocycle on at complex formation. The hosts 2-6 revealed stronger interaction with divalent metal ions than the hosts 1 and 7 which had no phenolic side arm. Under a basic condition, the hosts 5 and 6 containing an electron-withdrawing substituent produced larger stability constants with metallic guests than the hosts 2 and 3 containing an electrondonating group. The substituent effect is attributed to the solvent effect in which the aryl oxide with an electrondonating substituent has a tendency to be tied strongly with protic solvents. This fact and the stability constants of $\mathbf{8}$ demonstrate that phenolic side arms play a more important role than the azacrown ether ring in the process of making a complex with metal ions especially under a basic condition.

Acknowledgment. This work was supported by Korea Research Foundation Grant (KRF-2000-015-DP0270).

\section{References}

1. (a) Tsukulb: 1I, J. Coordination (hem. 1987, B-/6, 101. (b) Krakowiak. K. İ.: I3radshaw. I. S.: /amecki-Krakowiak. D. I. (hem. Rev 1989. 89. 929. (c) l lancock. R. D.: Martell. A. L. Chem. Rev. 1989. S9. 1875. (d) I latt. R. M.: l'anlak. K.: Bradshaw: J. S. Chent. Rev: 1995. 95. 2529.

2. (a) Echogoyen. L. E.: Yoo. H. K.: Gatto. V. I.: Gokel. G. W.: Fchegoyen. I. J. An. (hem. Soc. 1989. H/, 2440. (b) Tsukulx. Il: Araki. T. Liquid Hembrames: (hemistry dpplications: CRC press: Forida 19y0. (c) lsukube. II.: Iemishi. I.: I ligaki. Il: Kikkawa. K.: Ianata. I: Wakabayashi. S.: Oae. S. J. Org. Chem. 1993. 58. 4389. (d) Zhang. X.: Bordunov. A. V.: Bradshaw. I. S.: 
Dalley: N. K.: Kol. X: Izatt, R. M. J. Am. Chem. Soc. 1995. 117. 11507. (e) Su. N.: Bradshaw. J. S.: Zhang. X. X.: Song. H.: Savage. P. B.: Xue. G.: Krakowiak. K. E.: Izatt. R. M. J, Org.Chent 1999.64 .8855 .

3. (a) Tramontini. M. Symthesis 1973, 703. (b) Trannontini. M: Angiolini. L. Tetrahedron 1990, 46, 1791. (c) Page, P. C. B. Heanev. H. Sampler. E. P. J. Am. Chem. Soc. 1999. 121.6751.

4. (a) Lukyanenko. N. G.: Pastushok. V. N.: Bordunov. A. V. Synthesis 1991. 241. (b) Lukyanenko. N. G.: Pastushok. V. N.: Bordunov. A. V: Vetrogon. V. I.: Vetrogon. N. I.: Bradshaw. J. S. J. Chem. Soc. Perkin Trans. 1 1994, 1489. (c) Habata, Y: Saeki. T: Watanabe, A.: Akabori. S: Bradshaw. J. S. J. Heterocychic Chem. 1999. 36. 355 .

5. (a) Chi. K.-W.: Wei. H.-C.: Kottke. T.: Lagow. R. J. J. Org. Chent. 1996. 61. 5684. (b) Chi. K.W. Ahn. Y. S.: Shim. K. T: Park. T. H.: Ahn. J. S. Bull Korean Chen. Soc. 1999. 20.973. (c) Su. N.: Bradshaw I. S.: Savage, P. B.: Krakowiak. K. E: Izatt R. M.: De Wall. S. L.: Gokel. G. W. Tetratredron 1999, $55,9737$.
6. Martell, A. E; Motekaitis, R. J. Detemmination and Use of Stability Constants. 2nd ed.: VCH: New York. 1992: pp 129-172.

7. Connors. K. A. Binding Constamts: The Heastrement of Molecular Conplex Stability: John Wiley and Sons: New York. 1987.

8. Izatt, R. M; Pawlak. K.; Bradshaw, J. S. Chenical Review' 1991. 91. 1894. The constants were obtained by potentiometric method in $\mathrm{H}_{2} \mathrm{O}$.

9. The $\mathrm{K}_{\mathrm{YL}}$ was defined and calculated by the BEST program. And the result of CIS experiment under a basic condition indirectly indicates an easy formation of the complex $\mathrm{ML}$.

10. Izatt, R. M; Pawlak. K; Bradshaw, J. S. Chemical Review's 1991. 91. 1895-1897. The constants were obtained by potentiometric method in $\mathrm{MeOH}$.

11. Irving. H. R.: Willams. J. P. Chem. Conmm 1953. 3192 .

12. Amstrong. L. G.: Lindoy. L. F. J. Horg. Chent 1975. 14. 1322.

13. Smith. M. B.: March. J. Advanced Organic Chemistry 5th ed. John Wiley and Sons: New York. 2001; pp 368-375. 